\title{
APRESENTAÇÃO
}

\section{O fenômeno religioso por diferentes abordagens}

O fenômeno religioso tem sido objeto de investigação social sob as mais diferentes perspectivas, a rigor, desde a constituição das ciências sociais modernas, ainda no século XIX. No passar do tempo, somou-se a este campo teórico diferentes abordagens disciplinares que lhe avaliam a partir de saberes múltiplos e instigantes. Assim, ainda que dentro do escopo das ciências sociais, o fenômeno religioso contemporâneo e suas mais diferentes facetas são avaliados por olhares que levam em conta as suas dimensões: histórica, filosófica, arquitetônica, estética, imagética, simbólica, política, jurídica, teológica assim por diante. Este aspecto moderno e interdisciplinar de sua avaliação é produto de sua complexidade e dos intercâmbios disciplinares e intelectuais promovidos pelas redes de pesquisa locais e estrangeiras cada vez mais conectadas e em diálogo constante.

Ao que tudo indica e malgrado as dificuldades intrínsecas de sua complexidade que atentam contra as grandes generalizações outrora credoras de nossa exegese científica, o conhecimento atual sobre o fenômeno religioso só faz crescer e se sofisticar. Neste sentido, este número de Ciencias Sociales y Religión/Ciências Sociais $e$ Religião apresenta alguns estudos realizados em diferentes épocas e locais do subcontinente americano e que atravessam múltiplas expressões do fenômeno religioso, sobre diversos olhares e perspectivas. Assim, em seu próprio tempo histórico, mediante o atual volume e seus predecessores, esta Revista procura se manter enquanto contribuinte privilegiada do entendimento acerca deste fenômeno, tanto na atualidade quanto em tempos passados, especialmente no que se refere ao universo latinoamericano.

Neste sentido, iniciamos este volume a partir de dois trabalhos que investigam a questão religiosa atual sob o ponto de vista de sua pertença em matriz africana. $\mathrm{O}$ primeiro texto, de Júlio Cesar Tavares Dias, $O$ doce de Cosme e Damião: entre o sincretismo afro-católico e a recusa evangélica, avalia um expediente deveras importante para as algumas religiões, como para o catolicismo popular e as de matriz africana que se trata do alimento, que, neste caso, como costuma ocorrer em outras situações, também é alvo de sincretismos que acabam por criar constructos e sínteses inteiramente particulares. Dado que os santos católicos Cosme e Damião foram, nas religiões afro-brasileiras, sincretizados com os erês (espíritos de crianças), esses doces são ofertados como promessas, no catolicismo popular, ou se tratam de oferenda aos Orixás (entidades dos cultos afro). Assim o autor também avalia a atitude recente dos evangélicos, principalmente pentecostais, de recusá-lo, como também a reconfiguração dessa prática que faz a Igreja Universal do Reino de Deus ao distribuir doces deste tipo, mas consagrados, temendo que as crianças fiquem "endemoninhadas" ao comer os demais.

O campo afrorreligioso, através da Umbanda, também é objeto de análise no trabalho a seguir, de Andres Serralta Massonnier, mas a partir de sua presença em outro 
país que não o seu de origem. Neste caso, em Umbanda en un país laico. La pugna umbandista por el espacio público uruguayo, o autor investiga o desenvolvimento desta religião naquele país tido por muitos pesquisadores como o de maior tradição secular da América do Sul. Por esta razão, revela-se no texto uma série de dificuldades atinentes ao enraizamento desta religião naquele país, no sentido de lograr maior aceitação e legitimidade social, quadro que só pode se transformar de maneira mais positiva a partir da restauração da democracia no país em 1985, o que, de qualquer modo, não encerrou as tensões existentes entre as distintas confissões e entre elas e o Estado, avaliadas no tempo presente. Todavia destacamos que ambos os autores que abrem este volume foram agraciados com o prêmio de destaque no concurso de Jovens Pesquisadores promovido pela Associação dos Cientistas Sociais da Religião do Mercosul, responsável por este Periódico.

Do Uruguai, tido como a "nação mais laica da América Latina", regressamos ao Brasil a fim de avaliarmos justamente a questão da laicidade a partir do estudo de Matheus Oliva da Costa, intitulado: Diretrizes curriculares nacionais do Ensino Religioso: uma proposta fundamentada na Ciência da Religião. Neste trabalho, o autor apresenta alguns parâmetros para o Ensino Religioso em forma de um quadro sistemático no intuito de propor uma matriz nacional para essa disciplina, e que pode servir de modelo para um futuro plano nacional em termos de: conteúdos, objetos de estudo, objetivos e metodologias para essa área. Neste sentido, este texto pode ser entendido como uma perspectiva particular a respeito de um tema que ainda consiste em alvo de intenso debate e disputa entre diferentes setores da sociedade nacional.

E é justamente o segmento neopentecostal aquele que tem se interposto com mais evidência à secularização do Estado brasileiro a partir da atividade de diferentes igrejas. Assim, Paulo Passos, em De deserdados a empreendedores: os alicerces fáticos da identidade espiritual da Igreja neopentecostal Fonte da Vida, investiga o percurso de consolidação de uma dessas igrejas, que não tem recebido a mesma atenção se comparado a outras denominações. Dentre outros aspectos, como o estreitamento de relações com a política e com a mídia, neste trabalho o autor também procura conhecer o perfil socioeconômico da clientela religiosa da Igreja Fonte da Vida, assim como suas novas aspirações subjetivas ao demandarem os serviços religiosos.

O texto a seguir, de Ari Pedro Oro e Marcelo Tadvald, A Igreja Universal do Reino de Deus e a reconfiguração do espaço público religioso brasileiro, analisa o protagonismo desempenhado por esta que se trata, possivelmente, da mais notória denominação neopentecostal, no sentido de produzir reconfigurações no atual espaço público religioso brasileiro, o que ocorre em diferentes dimensões. Assim, este texto se detém especialmente na produção iurdiana da monumentalização do religioso, através da edificação das chamadas catedrais da fé, implantadas em lugares estratégicos das cidades. Assim procedendo a Universal desafia a hegemonia católica de se estabelecer como religião legítima no espaço público, ao mesmo tempo em que suas megaconstruções tendem a provocar um efeito mimético em outras formações religiosas que com ela competem no espaço público. O resultado disso é a diversificação e a ampliação do religioso neste espaço, sendo esta uma perspectiva para se entender a secularização brasileira. 
A seguir, o artigo de Agustina Altman e Alejandro Martín López, Compañeras o acompañantes? Mujeres menonitas misioneras en Argentina, explora o papel desempenhado pelas mulheres menonitas em suas missões religiosas desde a sua chegada ao país em 1917 até a década de 1960. Os menonitas formam um grupo de denominações cristãs que descende diretamente do movimento anabatista que surgiu na Europa no século XVI dentro do contexto mais geral da reforma da Igreja. Perseguidos historicamente, muitos desses grupos migraram para outras regiões, como a Argentina, país no qual os autores avaliam a presença a partir de fontes diversas de arquivo como: diários pessoais, cartas, publicações e outros materiais, no intuito de recuperar o papel, muitas vezes invisibilizado, que foi desempenhado por mulheres nas missões religiosas. Deste modo o trabalho procura contribuir não somente ao tema das missões em si, como também ao debate sobre as concepções e práticas de gênero no contexto do cristianismo da primeira metade do século XX.

A devoção mariana no extremo sul do continente é tema do trabalho: Devotos, ofrendas y promesas en el espacio religioso de la Virgen de las Nieves en San Carlos de Bariloche, Argentina, de Maria Andrea Nicoletti e Ana Inés Barelli, em que as autoras abordam desde a geografia da região a devoção em questão a partir dos sujeitos envolvidos. A gruta onde repousa tal devoção se constitui como território sagrado e que conta com dinâmicas próprias que a torna cenário simbólico particular, analisado mediante as oferendas materiais ali encontradas e as promessas realizadas pelos devotos.

Em Sin atajos para la revolución. La Iglesia Católica en Brasil y la conformación de la intelectualidad católica de izquierda (1950-1985), Pia Paganelli avalia a maneira pela qual se configurou uma intelectualidade católica de esquerda na região e que a partir dos anos 1970 se vinculou com a Teologia da Libertação, a partir da análise da trajetória institucional e desses grupos sociais no Brasil. Assim o artigo busca compreender a relação entre a Igreja com o Estado no período em questão que atravessa o regime autoritário instaurado em 1964 e que produziu permanências que repercutem até os dias atuais no vasto quadro dos movimentos sociais existentes.

A seguir, Denilson Geraldo e Maria José Sousa de Aguiar, no trabalho: O pobre no espírito e rico em humanidade, a partir da parábola "Felizes os pobres no espírito, porque deles é o Reino dos Céus" (Mt 5,3), abordam certos princípios bíblicos e morais que orientam a Igreja, mediante a atuação de bispos latino-americanos, para o anúncio profético e libertador do Evangelho e para a denúncia das injustiças e da opressão presentes no continente.

Por fim, em: Tempo e lugar em Michel de Certeau: implicações para os estudos de religião, Adriel Moreira Barbosa analisa dois importantes conceitos de Michel de Certeau: "tempo e lugar". Eles formam um fio condutor de suas teses quanto ao processo do fazer historiográfico, que segundo De Certeau, é uma construção realizada por um sujeito, o historiador. Esta construção implica em muitas influências no decorrer de suas etapas, o que De Certeau nos explica através de sua linguagem carregada de metáforas e com grande erudição. A importância das teses de Michel de Certeau para a historiografia tem sido amplamente destacada, e neste texto busca-se destacar suas implicações nos estudos de religião. 
Desejo-lhes uma boa leitura.

Porto Alegre, dezembro de 2015.

Dr. Marcelo Tadvald Editor-Gerente 